\title{
EFFECT OF RECOMBINANT BOVINE SOMATOTROPIN ADMINISTRATION ON MILK PRODUCTION, COMPOSITION AND SOME HEMATO-BIOCHEMICAL PARAMETERS OF LACTATING GOATS
}

\author{
S. M. A. Sallam ${ }^{1}$, M. E. A. Nasser ${ }^{1}$ and M. I. Yousef ${ }^{2}$ \\ 1- Department of Animal Production, Faculty of Agriculture, Alexandria University, \\ Alexandria, Egypt, 2- Department of Environmental Studies, Institute of Graduate \\ Studies and Research, Alexandria University, Alexandria, Egypt
}

\section{SUMMARY}

The objectives of the present study were to evaluate the effects of recombinant bovine somatotropin (rbST) on milk production, and composition and some hematobiochemical characteristics in Damascus goats. Fifteen Damascus lactating goats in their third to fourth lactation season and at 30-40 days postpartum were divided into three equal groups. The first group was served as control, while the second and the third groups were subcutaneously and biweekly injected for 8 weeks, with low (50 mg/doe) or high (100 mg/doe) doses of rbST, respectively. Administration with rbST resulted in a significant $(P<0.05)$ increase in total milk yield by 24.3 and $22.5 \%$ for $50 \mathrm{mg}$ or $100 \mathrm{mg}$ of rbST, respectively compared with control. Body weight and dry matter intake of does were not affected significantly by rbST treatment. While, average daily gain (ADG) of kids suckling rbST-treated does was higher by (11 and $10.5 \%$ for low and high doses of rbST, respectively) than for kids of control does during the treatment period. Administration with rbST caused insignificant $(P>0.05)$ increase in the levels of total solids, milk protein and fat compared with control, while lactose was significantly $(P<0.05)$ increased. On the other hand, ash, hematological parameters, plasma proteins and the activities of plasma aspartate aminotransferase (AST), alanine aminotransferase (ALT), glutathione S-transferase (GST), alkaline phosphatase (AlP), acid phosphatase (AcP), and the levels of thiobarbituric acid-reactive substances (TBARS), creatinine and cholesterol were not significantly affected by the treatments. Administration of rbST significantly $(P<0.05)$ increased the concentrations of plasma glucose and decreased those of urea and total bilirubin. The results of the present study suggest that rbST is efficacious in increasing milk yield and kid growth up to $50 \mathrm{mg} / 14 \mathrm{~d}$ without adverse effects on lactating goats.

Keywords: Somatotropin; Goat; Milk composition; Blood metabolites.

\section{INTRODUCTION}

Previous studies have demonstrated that somatotropin is a key control of nutrient use. When bovine somatotropin (bST) is exogenously administered, markedly 
improves productive efficiency in lactating cows (Peel and Bauman, 1987; Bauman, 1992). Lactational responses to bST have been reported for all dairy breeds examined, including North American and European breeds as well as Murrah buffalo. In addition, animals of different parities and genetic potentials are responsive to bST (Peel and Bauman, 1987). Improvement of productive efficiency and economic profit is an important goal in dairy farming, as in any agricultural enterprise. With bST use, a unit of milk is produced with less feed and protein supplement and with a reduction in animal excreta (manure, urine, and methane). Nationally, the use of bST simply reinforces, but does not fundamentally change dairy industry trends of increased milk yield per cow, reduced number of cows, and declines cow and dairy farm numbers (Bauman, 1992). Administration of exogenous native pituitary or recombinant bovine somatotropin (rbST) significantly increases milk yield in dairy cattle, either in short(Chilliard, 1988a) or long-term (Chilliard, 1988b) experiments. Bauman (1992) reported that the maximum milk response is achieved at a bST dose (daily injection) of about 30 to $40 \mathrm{mg} / \mathrm{d}$, and no further increase occurs even at doses several fold higher. Although, the treatment of lactating sheep and goats with rbST resulted in an increased milk yield, but the trials with sheep and goats were of very short-term $(<14$ d.) which allowing a weak galactopoietic effect (Disenhaus et al., 1995). From the previous studies, there is a few experiments have been carried out with bST on lactating goats to investigate its repeated daily doses for short-term $(<14 \mathrm{~d}$.), but not for long-term and weekly or biweekly injection Therefore, this study was carried out to investigate the effects of two different doses of rbST, administrated biweekly in lactating goats on milk yield, milk composition, kids growth performance and some blood metabolites of lactating goats with single kid for 8 weeks.

\section{MATERIALS AND METHODS}

\section{Animal manegment and treatments}

The experiment was carried out at the Alexandria University Experimental Farm during spring 2003. Fifteen lactating Damascus does each weighing $29.12 \pm 1.34 \mathrm{~kg}$ with single kids at 30-40 days postpartum were used. Goats were in their third to fourth lactation season. The goats were kept in a free stall and had free access to water. They were fed on concentrate mixture and berseem hay twice daily at 0700 and $1500 \mathrm{~h}$. The diet was offered in amounts calculated to provide $120 \%$ of the NRC recommended amount (NRC, 1985). Individual intakes of berseem hay and concentrate were recorded daily. Weight of refusal feeds were recorded once daily. Feed was sampled once weekly and monthly was composite dried and ground. Berseem hay and concentrate were analyzed for dry matter (DM), crude protein (CP), ether extract and ash according to procedures of AOAC (1990) (Table 1). The animals were divided into 3 homogenous groups, 5 animals each, according to lactation stage, parity and milk yield. The first group was used as a control, while the second and third groups were subcutaneously injected with 50 or $100 \mathrm{mg}$ rbst/doe biweekly for 60 days. A sustained release formulation of rbST was purchased from Elanco-Eli Lilly export S.A., Geneva. 
Table 1. Chemical composition of commercial concentrate mixture and berseem hay

\begin{tabular}{lcc}
\hline Parameters (\%) & Concentrate & Berseem hay \\
\hline Dry matter & 89.44 & 91.45 \\
Organic matter & 83.59 & 80.33 \\
Crude protein & 12.45 & 11.05 \\
Crude fiber & 4.92 & 22.35 \\
Ether extract & 4.75 & 2.65 \\
Ash & 5.85 & 11.12 \\
Nitrogen free extract (NFE) & 61.47 & 44.28 \\
\hline
\end{tabular}

\section{Milk production and composition}

Milk yield was recorded twice weekly at 0700 and $1600 \mathrm{~h}$ by using weigh-suckleweigh technique (Williams et al., 1979). At approximately 0800am, kids were removed from their dams and placed in an adjacent pen. Following a 5-h separation period, the kids were weighed and then joined with their dams to nurse. After kids had finished nursing (approximately $15 \mathrm{~min}$ ), they were reweigh. Milk yield for the 5-h period was taken as the difference in kid weight before and after nursing. To determine milk composition, samples were obtained once weekly by hand milking out the ewes before allowing the lambs to nurse. The samples were collected into plastic vials preserved with Microtabs, stored at $4^{\circ} \mathrm{C}$, and analyzed for total solids by drying a weighed $10 \mathrm{ml} /$ sample to a constant weight at $105^{\circ} \mathrm{C}$ for 24 hours. Fat was determined using Gerber method. Milk protein was determined by Kjeldahl method $(\mathrm{N} \times 6.38)$. Ash was determined by evaporating $10 \mathrm{ml}$ of milk to dryness and ashed in a muffle furance at $450^{\circ} \mathrm{C}$ for 6 hours (or $600^{\circ} \mathrm{C}$ for 2 hours). Lactose was calculated using the following formula:

Lactose $=100-($ ash + moisture + fat + proteins $)$

\section{Hematological parameters}

Blood sampling was performed weekly throughout the 8-week experimental period. Blood samples were obtained in the morning before feeding and watering from the external jugular vein and were placed immediately in ice. Heparin was used as an anticoagulant and plasma was obtained by centrifugation and stored at $-20{ }^{\circ} \mathrm{C}$ until used for analyses. Uncoagulated blood was tested, shortly after collection, for hemoglobin $(\mathrm{Hb})$, total erythrocyte count (TEC), packed cells volume (PCV) and total leukocyte counts (TLC). Blood $\mathrm{Hb}$ concentration was determined by the cyanomethemoglobin procedure (Wintrobe, 1965). Erythrocytes and leukocytes were counted on AO Bright line hemocytometer using a light microscope.

\section{Biochemical parameters}

Plasma was analyzed for total protein (TP) by the Biuret method according to Henry et al. (1974). Albumin (A) concentration was determined according to Doumas et al. (1977). Globulin (G) concentration was determined as the difference between total protein and albumin. Plasma glucose concentration was estimated according to Hyvarinen and Nikkila (1962). Urea and creatinine were determined in plasma by the methods of Patton and Crouch (1977) and Henry et al. (1974), respectively. Plasma total bilirubin was measured using the method of Walters and Gerade (1970). Plasma was assayed for cholesterol by the method of Watson (1960). 
Plasma alanine aminotransferase (ALT) and aspartate aminotransferase (AST) activities were assayed by the method of Reitman and Frankel (1957). Alkaline phosphatase (AlP) activity was measured in plasma (Principato et al., 1985). For assaying acid phosphatase (AcP) activity, the method of Moss (1984) was used. Plasma lactate dehydrogenase (LDH) activity was determined by the method of Cabaud and Wroblewski (1958). Glutathione S-transferase (GST) activity was determined in plasma according to Habig et al. (1974), using p-nitrobenzylchloride as a substrate. Thiobarbaturic acid- reactive substances (TBARS) were measured in plasma by using method of Tappel and Zalkin (1959).

\section{Statistical analysis}

Data were analyzed by a General Linear Model (GLM) procedure using SAS statistical package (SAS, 1986). Variation between means were compared by Duncan's Multiple Range Test (Snedecor and Cochran, 1980). The following model was used:

$\mathrm{Y}_{\mathrm{ijk}}=\mu+\mathrm{a}_{\mathrm{i}}+\mathrm{b}_{\mathrm{j}}+\mathrm{ab}_{\mathrm{ij}}+\mathrm{e}_{\mathrm{ijk}}$

where:

$\mathrm{Y}_{\mathrm{ijk}}=$ experimental observation,

$\mu=$ Overall mean,

$\mathrm{a}_{\mathrm{I}}=$ treatment effect

$b_{j}=$ week effect

$a b_{i j}=$ interaction effect of treatment and week

$\mathrm{e}_{\mathrm{ijk}}=$ random error

\section{RESULTS}

\section{Body weight and feed intake}

Body weight (BW) and dry matter intake (DMI) of the does were not significantly $(\mathrm{P}>0.05)$ affected by rbST treatment (Table 2). Kids of rbST-treated does had higher average daily gain $(\mathrm{ADG})(\mathrm{P}<0.05)$ than the kids of control goats by 11 and $10.5 \%$ for $50 \mathrm{mg}$ and $100 \mathrm{mg} \mathrm{rbST}$, respectively (Table 2).

Table 2. Effect of rbST on body weight and dry matter intake (DMI) of lactating goats and on growth performance of their kids (Means \pm SE)

\begin{tabular}{l|c|c|c}
\hline \multirow{2}{*}{ Parameter } & \multicolumn{3}{|c}{ Group } \\
\cline { 2 - 4 } & Control & $50 \mathrm{mg} \mathrm{rbST}$ & $100 \mathrm{mg} \mathrm{rbST}$ \\
\hline No. of does & 5 & 5 & 5 \\
Initial weight $(\mathrm{kg})$ & $28.60 \pm 2.8$ & $29.75 \pm 3.1$ & $29.00 \pm 3.8$ \\
Final weight $(\mathrm{kg})$ & $28.25 \pm 2.6$ & $29.87 \pm 2.3$ & $28.90 \pm 2.6$ \\
DMI $(\mathrm{kg} / \mathrm{d})$ & $1.601 \pm 24$ & $1.649 \pm 22$ & $1.645 \pm 25$ \\
No. of kids & 5 & 5 & 5 \\
Initial weight $(\mathrm{kg})$ & $7.51 \pm 0.43$ & $7.43 \pm 0.55$ & $7.46 \pm 0.57$ \\
Final weight $(\mathrm{kg})$ & $13.76 \pm 0.76$ & $14.41 \pm 0.42$ & $14.37 \pm 0.7$ \\
ADG (g/d) & $104.20 \pm 6.26^{\mathrm{b}}$ & $115.76 \pm 5.28^{\mathrm{a}}$ & $115.16 \pm 8.51^{\mathrm{a}}$ \\
Improvement $(\%)^{*}$ & - & $11.0 \%$ & $10.5 \%$ \\
\hline ab Within a row, means with different superscript letters differ significantly $(\mathrm{p}<0.05)$. \\
* The improvement (\%) in ADG of kids suckling rbST-treated does was calculated as a percent of control \\
group.
\end{tabular}




\section{Milk yield and composition}

The treatment of does with rbST increased rapidly milk yield after the onset of treatment (Fig. 1). Average increases in milk yield for does treated with $50 \mathrm{mg}$ or 100 mg of rbST were 24.3 and $22.5 \%$ above the control group, respectively (Table 3). The improvement in milk yield was $35 \%$ in the first 3 weeks in does treated with 50 $\mathrm{mg}$ rbST and started to decline from the sixth week of treatment (Fig.1). While, the enhancement in milk yield due to the administration of $100 \mathrm{mg}$ rbST continued until the fifth week of the treatment and then declined. No significant difference was noted between the 50 and 100-mg treatment groups. The improvement in milk yield due to rbST treatment was concomitant with a slight increase in the percentages of total solids, protein and fat, but the percentages of ash did not alter with the treatment. Concentration of lactose significantly increased $(\mathrm{P}<0.05)$ in treated does with both 50 $\mathrm{mg}$ and $100 \mathrm{mg}$ of rbST as compared with the control (Table 3). The improvement in milk yield and composition was approximately similar in $50 \mathrm{mg}$ or $100 \mathrm{mg}$ of rbST treated animals.

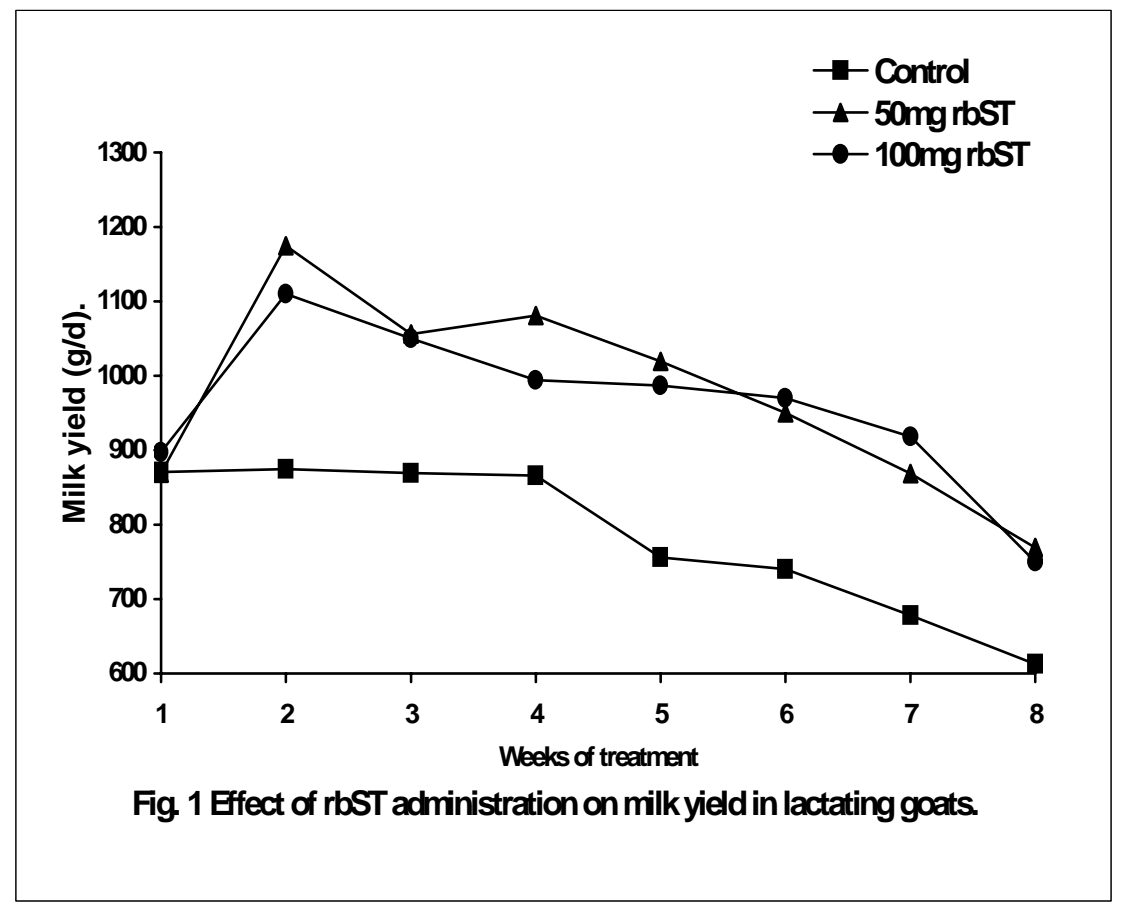


Table 3. Effect of rbST on milk yield and composition of lactating goats (Means \pm SE)

\begin{tabular}{lccc}
\hline Parameter & \multicolumn{3}{c}{ Group } \\
\cline { 2 - 4 } & Control & $50 \mathrm{mg} \mathrm{rbST}$ & $100 \mathrm{mg} \mathrm{rbST}$ \\
\hline Milk yield (g/d) & $783.5^{\mathrm{a}}$ & $973.5^{\mathrm{b}}$ & $959.5^{\mathrm{b}}$ \\
Improvement (\%)* & - & 24.3 & 22.5 \\
Milk Composition (\%): & & & \\
\hline Total solids & $13.29 \pm 0.31^{\mathrm{a}}$ & $13.97 \pm 0.34^{\mathrm{a}}$ & $13.92 \pm 0.46^{\mathrm{a}}$ \\
Protein & $3.49 \pm 0.14^{\mathrm{a}}$ & $3.60 \pm 0.04^{\mathrm{a}}$ & $3.65 \pm 0.13^{\mathrm{a}}$ \\
Fat & $4.06 \pm 0.13^{\mathrm{a}}$ & $4.18 \pm 0.08^{\mathrm{a}}$ & $4.17 \pm 0.10^{\mathrm{a}}$ \\
Lactose & $4.83 \pm 0.15^{\mathrm{b}}$ & $5.27 \pm 0.12^{\mathrm{a}}$ & $5.20 \pm 0.13^{\mathrm{a}}$ \\
Ash & $0.91 \pm 0.026^{\mathrm{a}}$ & $0.92 \pm 0.027^{\mathrm{a}}$ & $0.90 \pm 0025^{\mathrm{a}}$ \\
\hline abc Within a row, means with different superscript letters differ significantly & \\
(p<0.05). & & \\
* The improvement (\%) in milk yield of rbST-treated does was calculated as a percent of control group.
\end{tabular}

\section{Hemato-biochemical parameters}

The present data showed that hematological parameters (Hb, TEC, PCV, and TLC), plasma proteins (TP, A and G), enzyme activities (AST, ALT, AcP, AlP, and GST) and the levels of thiobarbituric acid-reactive substances did not change in treated does with both $\mathrm{rbST}$ administration as compared to the control animals (Tables 4 and 5). Treatment with low or high doses of rbST caused significant $(\mathrm{P}<0.05)$ decrease in the levels of plasma urea and total bilirubin in a dose dependent manner. While, the concentrations of creatinine and cholesterol insignificantly $(\mathrm{P}>0.05)$ decreased. On the other hand, the levels of glucose significantly $(\mathrm{P}<0.05)$ increased in treated groups with both low and high doses of rbST compared to control (Table 4).

Table 4. Effect of rbST on hematological parameters of lactating goats (Means \pm SE)

\begin{tabular}{lccc}
\hline Parameter & \multicolumn{3}{c}{ Group } \\
\cline { 2 - 4 } & Control & 50 mg rbST & 100 mg rbST \\
\hline $\mathrm{Hb}(\mathrm{g} / \mathrm{dl})$ & $14.5 \pm 0.21$ & $14.5 \pm 0.25$ & $14.3 \pm 0.23$ \\
$\mathrm{PCV} \%$ & $30.1 \pm 0.67$ & $29.7 \pm 0.76$ & $29.4 \pm 0.49$ \\
Erythrocytes $\left(\times 10^{6}\right)$ & $9.4 \pm 0.29$ & $9.6 \pm 0.47$ & $9.2 \pm 0.41$ \\
Leukocytes $\left(\times 10^{3}\right)$ & $8.9 \pm 0.49$ & $8.7 \pm 0.31$ & $8.6 \pm 0.54$ \\
Total protein $(\mathrm{g} / \mathrm{dl})$ & $7.7 \pm 0.25$ & $7.8 \pm 0.26$ & $8.0 \pm 0.30$ \\
Albumin $(\mathrm{g} / \mathrm{dl})$ & $4.8 \pm 0.19$ & $5.1 \pm 0.20$ & $4.8 \pm 0.23$ \\
Globulin $(\mathrm{g} / \mathrm{dl})$ & $2.9 \pm 0.23$ & $2.7 \pm 0.29$ & $3.1 \pm 0.37$ \\
Glucose $(\mathrm{mg} / \mathrm{dl})$ & $52.4 \pm 2.28^{\mathrm{b}}$ & $75.1 \pm 2.58^{\mathrm{a}}$ & $78.9 \pm 1.84^{\mathrm{a}}$ \\
Urea $(\mathrm{mg} / \mathrm{dl})$ & $55.3 \pm 1.87^{\mathrm{a}}$ & $38.9 \pm 0.97^{\mathrm{b}}$ & $36.0 \pm 1.39^{\mathrm{b}}$ \\
Creatinine $(\mathrm{mg} / \mathrm{dl})$ & $0.78 \pm 0.049^{\mathrm{b}}$ & $0.70 \pm 0.043$ & $0.73 \pm 0.025$ \\
Total bilirubin $(\mathrm{mg} / \mathrm{dl})$ & $1.44 \pm 0.15^{\mathrm{a}}$ & $1.16 \pm 0.110^{\mathrm{b}}$ & $0.88 \pm 0.074^{\mathrm{c}}$ \\
Cholesterol $(\mathrm{mg} / \mathrm{dl})$ & $80.8 \pm 2.96$ & $77.5 \pm 2.5$ & $78.6 \pm 3.55$ \\
\hline abc Within a row, means with different superscript letters differ significantly $(\mathrm{p}<0.05)$ &
\end{tabular}


Table 5. Effect of rbST on some plasma biochemical parameters of lactating goats (Means \pm SE)

\begin{tabular}{lccc}
\hline Parameter & \multicolumn{3}{c}{ Group } \\
\cline { 2 - 4 } & Control & $\mathbf{5 0}$ mg rbST & 100 mg rbST \\
\hline AST $(\mathrm{U} / \mathrm{L})$ & $54.5 \pm 3.88$ & $49.5 \pm 3.48$ & $48.9 \pm 3.63$ \\
ALT $(\mathrm{U} / \mathrm{L})$ & $32.7 \pm 1.49$ & $33.1 \pm 2.05$ & $29.7 \pm 1.38$ \\
AcP $(\mathrm{U} / \mathrm{L})$ & $4.2 \pm 0.19$ & $4.8 \pm 0.68$ & $4.5 \pm 0.22$ \\
AlP(U/L) & $54.5 \pm 1.57$ & $55.5 \pm 2.02$ & $52.9 \pm 2.93$ \\
GST $(\mu \mathrm{mol} / \mathrm{hr})$ & $0.57 \pm 0.017$ & $0.61 \pm 0.021$ & $0.58 \pm 0.013$ \\
TBARS $(\mathrm{nmol} / \mathrm{ml})$ & $2.12 \pm 0.108$ & $1.88 \pm 0.078$ & $1.82 \pm 0.083$ \\
\hline
\end{tabular}

AST: Aspartate aminotransferase; ALT: Alanine aminotransferase; AcP: Acid phosphatase; AlP: Alkaline phosphatase; GST: Glutathione S-transferase; TBARS: Thiobarbituric Acid-reactive Substances

\section{DISCUSSION}

The insignificant increase in body weight (BW) and dry matter intake (DMI) with rbST administration in the present study (Table 2) is in agreement with Disenhaus et al. (1995), Davis et al. (1999) in goats and Chilliard (1988a) in cows. However, the response to somatotropin can be variable. For example, Tripp et al. (1998) reported that ST injection resulted in increased body weight gain and feed efficiency. The present results showed that average daily gain (ADG) of kids that were suckling rbST-treated does was higher than for kids of untreated does during treatment period (Table 2). Also, Davis et al. (1999) found that average daily gain of kids that were suckling bST-treated does was higher $(\mathrm{P}<0.05)$ than for kids of untreated does. From the present data it is clear that the increase in ADG of the kids of rbST-treated does was affected without change in DMI or BW of does. Similar responses in milk yield by lactating goats and cows without corresponding increase in DMI have been reported by Peel and Bauman (1987) and Davis et al. (1999). McLaughlin et al. (1991) reported that performance responses due to treatment with bST were reflected by changes in circulating glucose, blood urea nitrogen, and insulin-like growth factor I (IGF-I) concentrations. Also, Min et al. (1997) and Faulkner (1999) found that bST increased IGF-1 in milk and plasma and could be one of the processes involved in stimulating milk synthesis. Prosser et al. (1991) demonstrated that increased milk secretion occur in goats in which milk and mammary IGF-1 concentrations increased.

In general, milk response is very small or negligible when bST is administered in early lactation during the interval immediately postpartum and prior to peak milk yield (Bauman, 1992). For the 8 weeks treatment period at 30-40 days postpartum, both doses of rbST resulted in a significant $(\mathrm{P}<0.05)$ increases in milk yield $(24.3 \%$ for does treated with $50 \mathrm{mg}$ and $22.5 \%$ for does treated with $100 \mathrm{mg}$ ) compared with milk yield of does on the control group. The pattern of milk yield response to sustained-release rbST in the present study (Fig. 1) was similar to that reported due to daily injection in goats (Disenhaus et al., 1995) and in cows (Chilliard, 1988b). The average response of goats injected daily with $\mathrm{rbST}$ at $5 \mathrm{mg} / \mathrm{d} / \mathrm{animal}$ was $28.6 \%$ increase in milk production for short-term experiment (28 days, Disenhaus et al., 1995). Also, Disenhaus et al. (1992) found that, for lactating goats injected daily with rbST for $4 \mathrm{wk}$, milk yield increased significantly and exceeded the yield of untreated 
goats by nearly $26 \%$. This finding is similar to the present results of both doses of rbST (Table 3). Somatotropin is a homeorhetic controller that shifts the partitioning of nutrients so that more are used for milk synthesis (Peel and Bauman, 1987). Thus, effects are primarily, perhaps exclusively, on directing the use of absorbed nutrients. This involves coordinating the metabolism of various body organs and tissues. These orchestrated changes in tissue metabolism involve both direct effects on some tissues (e.g., adipose, liver) and indirect effects mediated by somatotropin-dependent somatomedins (e.g., IGF-1) for other tissues (e.g., mammary) (Bauman, 1992). The mechanism of bST to exert its galactopietic effect is complex and involves a multiplicity of events in whole animal. The results obtained by Faulkner (1999) indicated that there were increases in the availability of glucose within the mammary epithelial cell in response to growth hormone treatment that would result in increases in the rate of lactose synthesis and hence stimulation of milk production. Also, they found increases in the concentrations of IGF-1 in milk and plasma and could be one of the processes involved in stimulating milk synthesis. In addition, somatotropin appears to promote milk production by a partitioning effect on absorbed nutrients, so to supply more substances for mammary synthesis, and also the level of nutrition may influence yield responses for milk and milk composition, and nutrient flow in bST-treated lactating ruminants (Bauman and Currie, 1980). Also, the increase in milk synthesis with STH treatment most likely involves changes in the activity of key regulatory enzymes resulting in an increased synthesis rate per epithelial cell. However, the possibility of an increase in mammary cell numbers cannot be excluded. In either case, somatotropin affects the maintenance of lactation as evidenced by the changes observed in the shape of the lactation curve (Bauman and Eppard, 1987). This role would presumably involve an altered turnover of epithelial cells and cellular components so that the normal loss of cells or the normal decline in biochemical activity per cell was reduced with STH treatment (Bauman and Eppard, 1985).

Gross composition of milk (fat, protein, and lactose content) is not substantially altered due to bST administration (Peel and Bauman, 1987). Linn (1988) reported that milk components have been examined in most bST production trials. There can be minor changes, primarily in fat content of milk, during the first few weeks of bST supplementation as the cow's metabolism and voluntary feed intake adjust. However, these changes are temporary and minor when compared with variations normally occurring over a lactation cycle. Although, the lactose content of milk is relatively constant, the content of fat and protein normally varies widely because of many factors, including genetic, breed, stage of lactation, age, diet composition, nutritional status, environment and season. The present results showed that there is no significant difference between control and treated groups with low or high doses of rbST in the average values of milk protein, total solids, fat and ash, while lactose levels increased (Table 3). Also, there is no change in milk composition in response to bST was observed in goats (Davis et al., 1999). The ability of bST to spare amino acids from catabolism and consequently to decrease urinary excretion of nitrogen was demonstrated (Disenhaus et al., 1995). The increase in lactose level (Table 3) is in agreement with the finding of Molento et al. (2002) found that milk yield, lactose percent, lactose yield and IGF-I levels were increased during rbST administration. In addition, Min et al. (1997) reported that treatment with bovine growth hormone increased yields of milk, fat, lactose and weight of the mammary gland. 
Urea concentration in plasma may be diminished by bST treatment. The decrease in plasma urea (30 and $40 \%$ for low or high doses, respectively) of does treated with rbST (Table 4) is in agreement with the results of goats treated with bST (Disenhaus et al., 1995). Also, Davis et al. (1999) reported that changes in plasma concentration of glucose, total protein, or urea of lactating goats were observed in response to bST treatment. Mclaughlin et al. (1991) found that blood urea nitrogen was decreased in bST-treated lamb. Min et al. (1997) reported that treatment with bovine growth hormone increased circulating concentrations of growth hormone, insulin-like growth factor-I, and nonesterified fatty acids and decreased urea concentrations in ewes. In addition, Eisemann et al. (1989) found that plasma concentration urea-N and alphaamino-N decreased with bST in beef steers. Since the plasma levels of urea is the index of hepatic amino acids oxidation and of ruminal ammonia fermentation, therefore its decrease may reflect a higher amio acids removed from blood for milk protein biosynthesis.

Glucose homeostasis provides a clear example of the coordinated responses that occur with bST treatment of lactating cows (Bauman, 1992). With bST uses, glucose production by the liver increases, and its oxidation by body tissues decreases. Overall, these changes quantitatively are sufficient to account for the extra glucose required for milk synthesis by bST-treated cows (Bauman, 1992). The present results showed that plasma glucose increased by $43 \%$ and $51 \%$ for low or high doses of rbST. Eisemann et al. (1989) found that plasma concentration of somatotropin, insulin and glucose increased, while urea-N and alpha-amino-N decreased with bST in beef steers. Supplementation with bST may increase input of glucose into blood circulation by promoting gluconeogenesis from digestive precursors and from peripheral precursors, such as amino acids and glycerol (Knapp et al., 1992). Also, Molento et al. (2002) found that recombinant bovine somatotropin (40 mg/day for 6 days) caused a peripheral resistance to insulin or increased liver gluconeogenesis or both. The reduction in the ability of insulin to inhibit hepatic glucose synthesis and to stimulate glucose use by peripheral tissues represents a series of coordinated responses whereby more glucose can be used for milk synthesis while preserving the ability of the animal to maintain glucose homeostasis (Bauman, 1992). In addition, the effects on glucose and insulin has been reported in lactating cows and described usually as diabetogenic activity of bST (Chillard, $1988 \mathrm{a} \& \mathrm{~b}$ ). The importance of these effects in the shift of the partitioning of nutrients is also because the mammary gland processes can enhance lactose synthesis and the osmotic regulator of milk volume (Gallo and Block, 1990).

Table 4 showed that hematological parameters (Hb, PCV, TEC and TLC), plasma proteins (total protein, albumin and globulin), creatinine and cholesterol did not change in does treated with rbST as compared with control. Also, the activities of plasma AST, ALT, AcP, AlP and GST, and the concentrations of TBARS were not affected by rbST treatment as compared to the control group (Table 5). On the other hand, treatment with rbST caused reduction in total bilirubin concentration. Also, Eppard and Bauman (1987) reported that treatment with bST did not cause any significant change in $\mathrm{PCV}, \mathrm{HB}, \mathrm{RBC}, \mathrm{WBC}$, total protein, albumin, globulin, creatinine, AST, while blood urea nitrogen decreased in dairy cows. The activities of plasma AST and ALT, which are commonly used as indicators of liver cell damage and death, was not affected by the treatment with rbST (Gallo and Block, 1990). In addition, Davis et al. (1999) reported that treatment with bST did not affect plasma 
concentrations of total protein of lactating Angora does. Early et al. (1990) found that serum electrolytes, protein and most enzyme activities were similar in control and bST steers. Serum urea, creatinine and cholesterol concentrations, however, were lower in BST steers, suggesting that nitrogen retention was increased and lipid turnover was decreased by BST. Total and conjugated bilirubin concentrations and glutamate-pyruvate transaminase activity were lower in BST steers. Bauman and Eppard (1985) reported that milk yield responses to STH are perfectly coordinated with the alteration in the metabolism of body tissues as evidenced by the fact that steady state concentrations of blood metabolites are maintained (Tables 4 and 5). The increases in milk yield with rbST treatment (Table 3 and Fig. 1) could not persist through the treatment period unless coordinated changes occurred in body metabolism so that steady-state conditions were maintained. Eppard and Bauman (1987) reported that treatment with bST, physiological processes associated with carbohydrate, protein, lipid, and mineral metabolism all are coordinated to meet the increased mammary requirement for nutrients.

\section{CONCLUSION}

Administration of recombinant bST to lactating does once every other week for 60 days at 30-40 days postpartum increased milk yields (25\% and $23 \%$ for $50 \mathrm{mg}$ or 100 $\mathrm{mg}$, respectively) and kid growth. The levels of milk lactose and plasma glucose increased, but plasma urea decreased. While, there is no significant changes were found in body weight, dry matter intake, hemato-biochemical parameters and milk composition of treated does. Also, there is no significant difference was found between low $(50 \mathrm{mg})$ and high $(100 \mathrm{mg})$ doses of rbST. Based on these results, $\mathrm{rbST}$ is efficacious in increasing milk yield up to $24.3 \%$ and kid growth up to $50 \mathrm{mg} / 14$ days at 30-40 days postpartum without adverse effects on lactating does.

\section{REFERENCES}

Association of Official Analytical Chemists (AOAC), 1990. Official Methods of Analysis of the Association of Official Analytical Agricultural Chemists. $13^{\text {rd }}$ ed. AOAC Inc, Arlington, VA.

Bauman, D.E. and W.B. Currie, 1980. Partitioning of nutrients during pregnancy and lactation: a review of mechanisms involving homeostasis and homeorhesis. J. Dairy Sci., 63 :1514-1521

Bauman, D.E. and P.J. Eppard, 1985. Responses of high-producing dairy cows to long-term treatment with pituitary somatotropin and recombinant somatotropin. J. Dairy Sci., 68: 1352-1362.

Bauman, D.E., 1992. Bovine somatotropin: review of an emerging animal technology. J. Dairy Sci., 75: 3432-3451.

Cabaud, P. C. and F. Wroblewski, 1958. Calorimetric measurement of lactate dehydrogenase activity of body fluids. J. Clin. Pathol., 30: 234-236.

Chilliard, Y., 1988a. Effect of somatotropin growth hormone in lactating ruminants. Reprod. Nutr. Dev., 28: 39-59.

Chilliard, Y., 1988b. Long term effects of recombinant bovine somatotropin (rbST) on dairy cows performances (French). Ann. Zootech., 37: 159-180.. 
Davis, J.J., T. Sahlu, R. Puchala, M.J. Herselman, J.M. Fernandez, J.P. McCann, and S.W. Coleman, 1999. The effect of bovine somatotropin treatment on production of lactating Angora does with kids. J. Anim. Sci., 77: 17-24.

Disenhaus, C., J. Hervieu, F. Ternois, H. Jammes, G. Kann and D. Sauvant, 1992. Influnce d'injections quotidiennes de somatotropin bovine recombinee (rbST) sur la production laitiere, l'ingestion et l'etat nutritionnel de la chevre en lactation. Ann. Zootech., (Paris) 41: 109.

Disenhaus, C., H. Jammes, J. Hervieu, F. Ternois and D. Sauvant, 1995. Effect of recombinant bovine somatotropin on goat milk yield, composition and plasma metabolites. Small Rumin. Res., 15: 139-148.

Doumas, B.T., W.A. Watson and H.G. Biggs, 1977. Albumin standards and the measurment of serum albumin with bromocresol green. Clinic. Chem. Acta, 31: $87-96$.

Early, R.J., B.W. McBride and R.O. Ball, 1990. Growth and metabolism in somatotropin-treated steers: I. Growth, serum chemistry and carcass weights. J. Anim. Sci., 68: 4134-4143.

Eisemann, J.H., A.C. Hammond T.S. Rumsey and D.E. Bauman, 1989. Nitrogen and protein metabolism and metabolites in plasma and urine of beef steers treated with somatotropin. J. Anim. Sci., 67:105-115.

Eppard, P.J. and D.E. Bauman, 1987. Effect of 188-day treatment with somatotropin on health and reproductive performance of lactating dairy cows. J. Dairy Sci., 70: 582-591.

Faulkner, A., 1999. Changes in plasma and milk concentrations of glucose and IGF-1 in response to exogenous growth hormone in lactating goats. J. Dairy Res., 66: 207-214.

Gallo, G.E. and E. Block, 1990. Effect of recombinant bovine somatotropin on nutritional status and liver function of lactating dairy cows. J. Dairy Sci., 73: 3276-3286.

Habig, W.H., M.J. Pabst and W.B. Jakoby, 1974. Glutathione S-transferases. The first enzymatic step in mercapturic acid formation. J. Biol. Chem., 249: 71307139.

Henry, R.J., D.C. Cannon and W. Winkelman, 1974. Clinical Chemistry Principles and Techniques, $11^{\text {th }}$ ed. Happer and Row Publishers, 1629 pp.

Hyvarinen, A. and E.A. Nikkila, 1962. Determination of blood glucose with O.Toludine. Nut. Abst. Rev., 32: 589.

Knapp, J.R., H.C. Freetly, B.L. Reis, C.C. Calvert and R.L. Baldwin, 1992. Effects of somatotropin and substrates on patterns of liver metabolism in lactating dairy cattle. J. Dairy Sci., 75: 1025-1035.

Linn, J.G. 1988. Factors affecting the composition of milk from dairy cows. Page 224 in designing foods-animal product options in the marketplace. Natl. Acad. Press, Washington, DC.

McLaughlin, C.L., G.J. Rogan, F.C. Buonomo, W.J. Cole, G.F. Hartnell, S. Hudson, T.R. Kasser, M.A. Miller and C.A. Baile, 1991. Finishing lamb performance responses to bovine and porcine somatotropins administered by Alzet pumps. J. Anim. Sci., 69: 4039-4048.

Min, S.H., D.D. Mackenzie, S.N. McCutcheon, B.H. Breier and P.D. Gluckman, 1997. Comparative effects of recombinant ovine placental lactogen and bovine growth hormone on galactopoiesis in ewes. J. Dairy Sci., 80: 640-645. 
Molento, C.F., E. Block, R.I. Cue and D. Petitclerc, 2002. Effects of insulin, recombinant bovine somatotropin, and their interaction on insulin-like growth factor-I secretion and milk protein production in dairy cows. J. Dairy Sci., 85(4): 738-747.

Moss, D.W. 1984. Methods of Enzymatic Analysis, Bergmeyer, H.U., (Ed.), VerlagChemi., 4: 92-106.

NRC 1985. Nutrient Requirements of sheep. National Academy Press. Washington, DC.

Patton, C.J. and S.R. Crouch, 1977. Spectrophotometeric and kinetics investigation of the Berthelot reaction for determination of ammonia. Anal. Chem., 49: 464-469.

Peel, C.J. and D.E. Bauman, 1987. Somatotropin and lactation. J. Dairy Sci., 70: 474486.

Principato, G. B., M.C. Asia, V. Talesa, G. Rosi and E. Giovannini, 1985. Characterization of the soluble alkaline phosphatase from hepatopancreas of Squilla mantis L. Comp. Biochem. Physiol., 80B: 801-804.

Prosser, C.G., C. Royle, I.R. Fleet and T.B. Mepham, 1991. The galactopoietic effect of bovine growth hormone in goats is associated with increased concentrations of insulin-like growth factor-I in milk and mammary tissue. J. Endocrinol., 128: 457-463.

Reitman, S. and S.A. Frankel, 1957. Colorimetric method for the determination of serum glutamic oxaloacetic and glutamic pyruvic transaminases. Am. J. Clinic. Pathol., 28: 56-63.

Snedecor, G.W. and W.G. Cochran, 1980. Statistical methods. Iowa State Univ. Press, Ames, IA, USA.

Statistical Analysis System (SAS). 1986. Principles and Procedure of Statistics, $2^{\text {nd }}$ ed. Carry, NC, Mc Graw-Hill Inc.

Tappel, A.L. and H. Zalkin, 1959. Inhibition of lipid peroxidation in mitochondria by vitamin E. Arch. Biochem. Biophys., 80: 333-336.

Tripp, M.W., T.A. Hoagland, G.E. Dahl, A.S. Kimrey and S.A. Zinn, 1998. Methionine and somatotropin supplementation in growing beef cattle. J. Anim. Sci., 76: 1197-1203.

Walters, M. and H. Gerade, 1970. Ultramicromethod for the determination of conjugated and total bilirubin in serum or plasma. Microchem. J., 15: 231.

Watson, D.A., 1960. Simple method for the determination of serum cholesterol. Clin. Chem. Acta, 5: 589.

Williams, J., D.C. Anderson and D.D. Kress, 1979. Milk production in herford cattle. I. Effects of seperation interal on weigh-suckle-weigh milk production estimates. J.Anim. Sci., 49:1438-1442.

Wintrobe, M. M., 1965. Clinical Haematology. Lea and Febiger, Philadelphia. 
تأثير المعاملة بهرمون النمو المخلق علي إنتاج ومكونات اللبن وبعض المقاييس الهيماتولوجية و الكيموحيوية في الماعز الحلابة

صبحي محمد سلام، محمد عماد ناصرَ، مختار إبراهيم يوسف2

1- قسم الإنتاج الحيوانى، كلية الزراعة، جامعة الإسكندرية، 2- قسم اللداسات البيئية، معطل الدراسات العليا والبحوث، جامعة الإسكندرية، الإسكندرية النية

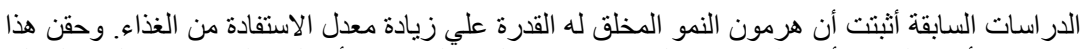

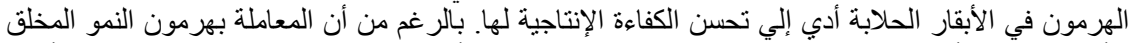

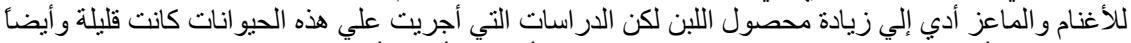

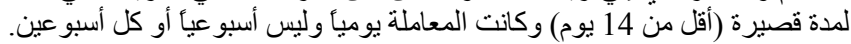

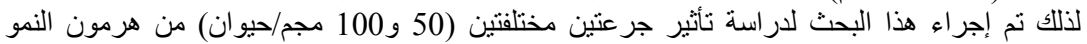

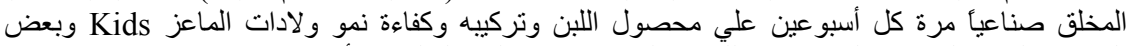

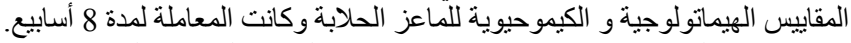

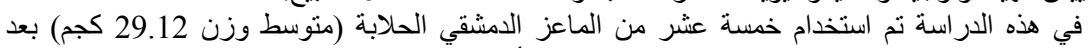

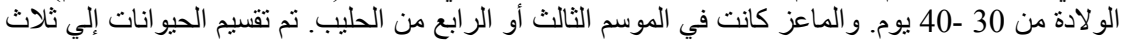

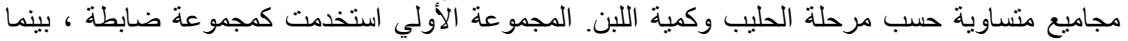

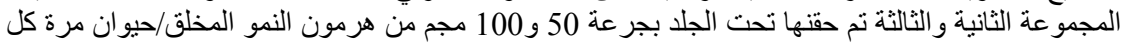
أسبو عين لمدة 60 يوم علي التو التي.

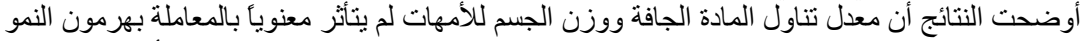

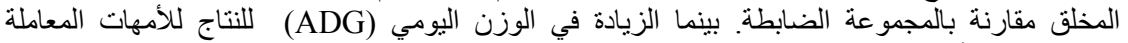

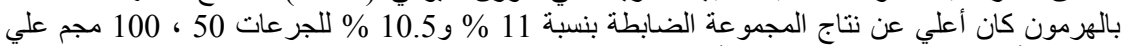

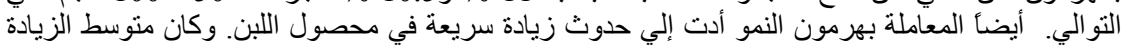

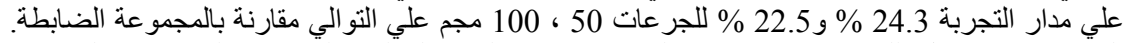

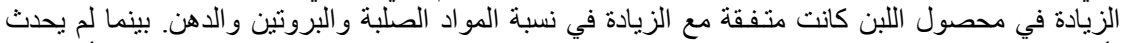

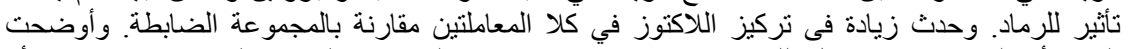

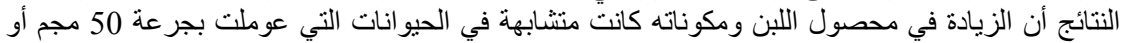

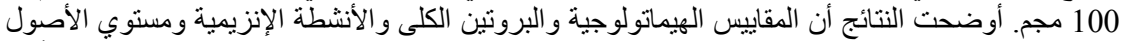

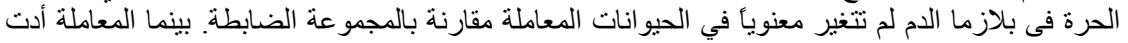

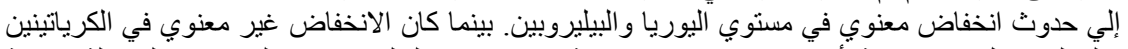
والكوليسترول. من ناحية أخري حدث زيادة معنوية في مستوي الجلوكوز في الحيوانات النيات المعاملة مقارنة بالمجمو عة الضابطة.

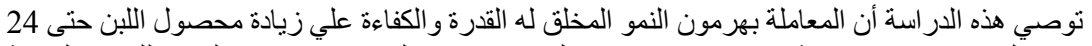

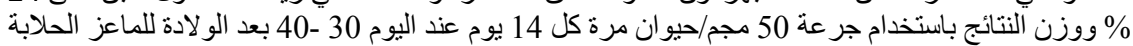
دون ظهور تأثير سلبي علي صحة الأمهات. 
